\title{
和歌山県に打りるギ花粉症の現状と対策
}

\author{
榎本 雅夫 ${ }^{1)}$ ・中西 弘 ${ }^{1)}$ ・横山 道明 11 \\ 寒川 高男1)・岩橋 大介(2) ・田端 敏秀3)

\section{Japanese Cedar Pollinosis and its Countermeasures in Wakayama Prefecture}

\author{
Tadao Enomoto, Hiroshi Nakanishi, Michiaki Yokoyama \\ and Takao Samukawa \\ (Wakayama Red Cross Hospital) \\ Daisuke Iwahashi \\ (Kainan Municipal Hospital) \\ Toshihide Tabata \\ (Wakayama Medical college)
}

Japanese cedar pollinosis has been increasing in its incidence year by year and is now one of the most common pollinoses in Japan. Cases of Japanese cedar pollinoses are also many in Wakayama Prefecture.

With intention to elucidate the nature of Japanese cedar pollinosis in Wakayama area, we have been doing the following studies in recent years: 1) Epidemiological study using Japanese cedar RAST (Radioallergosorbent test), 2) Measurement of the number of Japanese cedar pollens in the air, and 3) Immunological study of Japanese cedar specific IgG and its subclass antibodies on many clinical cases.

The results show the incidence of RAST positivity is $16.6 \%$ in the general public of Wakayama Prefecture, and it is higer in mountainous areas than in littoral areas, and also higer in the southern parts of the prefecture where plantation areas of Japanese cedar tress are wider.

The pollens tend to appear in the air first in the south, and are greater in number in Shingu City and Hashimoto City while they are not so many in Wakayama City. The number changes in a two-year cycle and there is a good correlation between the number of the pollens and the yearly incidence of the pollinosis. The statistical analysis of the measured number of pollens in the air and meteorological data was done to forecast the number of pollens in the future. But no good method of forecast has been developed probably due to insufficiency of data we have obtained.

In the study of incidence of positivity of Japanese cedar RAST and measurement of

1）和歌山赤十字病院耳鼻咽喉科

2）海南市民病院耳鼻咽喉科

3）和歌山県立医科大学耳鼻咽喉科学教室 
specific IgG and subclass antibodies, it is shown that the incidence of RAST positve subjects is highest in the age bracket of 20 to 30 years and is lower with increasing age. However, the amount of specific IgG and total IgG increases with aging. This result is of interest in view of the presence of a highest incidence of the pollinosis in a particular age bracket and the phenomenon of natural subsidence of the disease in individuals.

Based on our studies on this disease in Wakayama Prefecture with the comparison of studies of other Japanese researchers, our opinion on the coutermeasures is also stated.

Key words: Japanese cedar, pollinosis, Wakayama Prefecture

\section{はじめに}

早春から春に空中を飛散する花粉は主として 樹木花粉で, この様な木の花粉で発生する花粉 症には，ハンノキ112)， スギ344)，コナラ5)，シラ カンバ6), 七ノキ7), ケヤキ8), マッ9) 等々数多 くのものが報告されている。その中でも，スギ 花粉症は堀口, 斉藤4) ら（1964）に上り日光地 万で発見されてから年々増加しつつあり, 現在 日本を代表する花粉症となっている。ところで, 紀の国和歌山県は平野が少なく, 別名木の国と 呼ばれる汪ど山が多く, 長い海岸線と共に美し い自然には恵まれているものの，このシーズン には，ハンノキ，スギ，マッ，七ノキの花粉を はじめ多くの花粉が飛散してくる10).これらの 花粉の内, 臨床的に問題になるのは和歌山県で も発症患者数の多いスギ花粉症である（図 1 , $2)$.

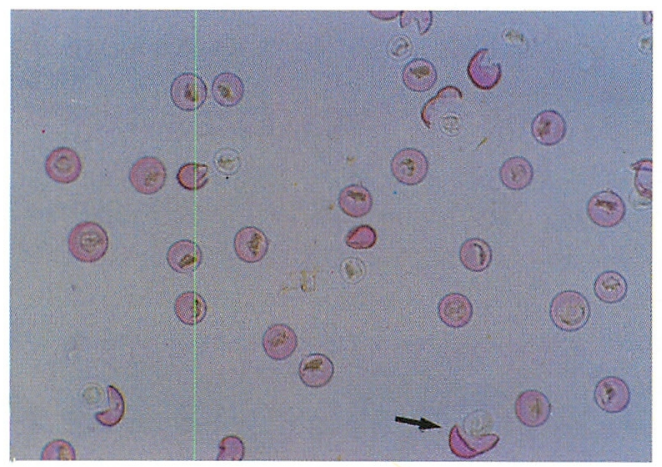

図 1 ゲンチアナバイオレットで染色したスギ花粉. 大ささ約 $30 \mu$. 透明感があり。花粉管口の 1 部がカギ状に曲がったパピラ（乳頭）を持つ. 矢印は吸水して破裂した破裂花粉を示す。
著者らはここ数年和歌山県地方に拈けるスギ 花粉症について種々の検討を行ってきた。 そこ で，その研究を中心として，和歌山県のスギ花 粉症の現状とその対策について考光てみたい。

\section{スギ花粉症について}

いわゆる花粉症の病因は19世紀になってから 判明したが，すでにとれらしき記載は紀元前か らあるとされている1112)。本邦に执いては，花 粉症は古くからあったのことが定説であるが， あまり問題とはなっていなかった．本格的に花 粉症の研究が始まったのは荒木13)（1960）の報 告からである。彼は東京都文京区，千葉県習志 野市で空中花粉の調査を行って，本邦にも tree season, grass season, ragweed season がある ことを報告した。 3 月の花粉曲線はほとんどが スギ花粉であることを報告しているものの，樹 木花粉のスギ花粉症がまだ問題になっていず,

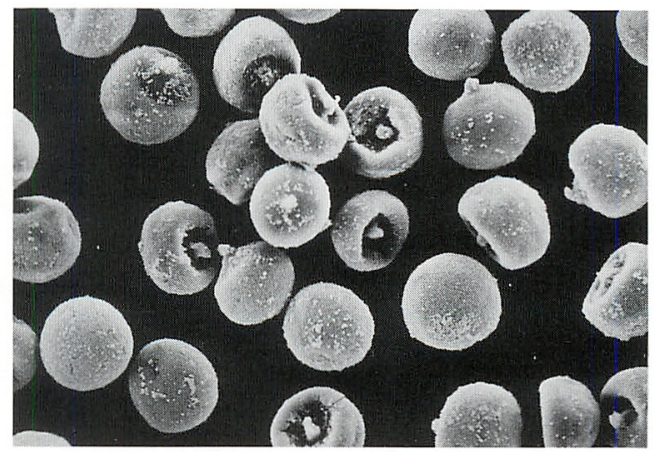

図 2 スギ花粉の走查電子顕徴鏡像. パピラを中心 に凹んでドーナッを呈するのは，乾燥した花 粉. 和歌山県立医科大学生物学教室平尾教授 撮影. 
あまり重要視していない、堀口・斉藤1) ら （1964）によって初めて日光地方のスギ花粉症 が紹介された. その後, 本症の増加に伴い日本 アレルギー学会, 日本耳鼻咽喉科学会, 日本鼻 科学会, 耳鼻咽喉科免疫アレルギー研究会, 日 本小児アレルギー学会, 日本眼科学会, 日本花 粉学会等の多くの学会でスギ花粉症の実態や病 態, 抗原の検索や分析, 治療に関する研究等が 数多く報告されている. 同時に, 多数の論文や

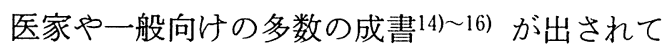
いる.

スギ花粉症の症状については，すでに成書に 詳しく報告されているし，また最近マスコミを 通じて一般の人々にも知れわたっている. 寸な わち，毎年 2 月から 4 月の決まった季節になる と, 鼻と眼の症状が主体2) で, くしゃみ, 水様 性鼻汁, 鼻閉などの鼻アレルギー症状, 眼の搔 痒感, 結膜の発赤, 充血, 流涙, 異物感, 羞明, 眼瞼浮腫などのアレルギー結膜炎の症状を引き 起こし, 重症例では咳嗽, 喘鳴, 悪心, 下痢, 便秘，最近では気管支喘息も報告されている17). 全身症状としては倦㤐感, 脱力感等々多彩な症 状を呈する．本症はその症状の激烈さや頻度の 多いこと, その発症時期が卒業, 入学, 就職な どの人生にとっても最も重要な時期と一致する ために社会的問題化までしている，また，本症

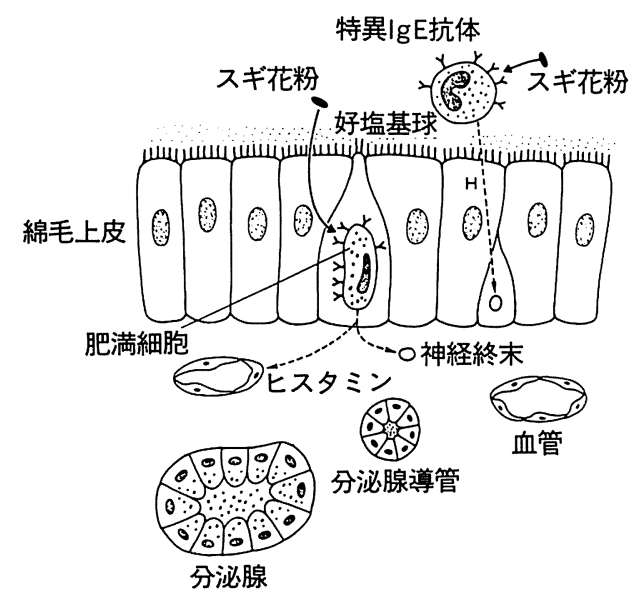

図 3 発症メカニズム (奥田稔: 1983 ${ }^{19)}$ より改変).
は20３0歳代の発症が多く，やや女性に多いと されている2)。また，最近学童期の子供にも増 加しつつあるとされている18).

発症メカニズムは，アレルゲンであるスギ花 粉により鼻粘膜にある好塩基球や肥満細胞から ケミカルメディエイター（ヒスタミン，ロイコ トリエン等）が放出され，先述の症状が発現す る典型的 I 型アレルギーであるとされている (図 3 ) 19).

\section{なぜスギ花粉が問題なのか}

花粉症の主たる発症メカニズムが I 型アレル ギーであるので，その発症率にはアレルゲンで ある花粉とそれに対する特異 $\operatorname{IgE}$ 抗体の持っ ている人の多少が大きく影響する。アレルゲン としての花粉側の要因としては，1）その花粉 に抗原性があること，2）花粉が大量に産性さ れること，3）花粉を産性する植物が広範囲に 分布し, しかも生育密度の高い事が必要となる. 1987年の林野庁計画課の統計によれば，本邦に おけるスギの樹林面積は $45091 \mathrm{Km}^{2}$ で総樹林 面積の $17.9 \%$ ，国土の $12.2 \%$ を占め，他の樹木 と比較して樹林面積が最も多く, 鼻汁や涙液な どの弱アルカリの溶液に触れると容易に花粉外 膜が破れ内容物が流出すること, 実際に飛散花 粉数を測定すると飛散数の最も多い花粉である こと等からスギ花粉は空中飛散花粉の内でも代 表的なものである。

表 1 17，18歳女子における樹木花粉 RAST 陽性 頻度 $(\mathrm{n}=230)$

\begin{tabular}{l|c}
\hline \hline アレルゲン & 陽性者数 \\
\hline カエデ & $6(2.6)$ \\
ハンノキ & $1(0.4)$ \\
ブナ & $3(1.3)$ \\
ビャクシン & $7(3.0)$ \\
カシ & $2(0.9)$ \\
カエデバスズカケノキ & $2(0.9)$ \\
スギ & $28(12.2)$ \\
\hline H.D. & $44(19.1)$ \\
ダニ (D.P.) & $62(27.0)$
\end{tabular}


一方, 抗体側の要因として, 著者ら ${ }^{20)}$ （1985） は各種の樹木花粉に対する $\operatorname{IgE}$ 抗体を持つも のが，一定の年代層でどの程度に存在するのか について検討したことがある。代表的な樹木の 花粉に対する RAST (radioallergosorbent test) 陽性率について検討したが，表 1 に示すように， 八ウスダストにはややその頻度で劣るものの， 樹木ではスギ RAST 陽性を示す症例が最も多 かった.これらのことは，樹木花粉のうちスギ 花粉が最も重要な花粉であることを示唆してい る.また， スギ花粉に RAST 陽性を示すもの ではそのほかの花粉やアレルゲンに陽性を示す ものが多かった211.

\section{和歌山県におけるスギ花粉症患者の頻度}

和歌山県に括けるスギの木は，天然スギ（図 4 ）が数千本の及で, 并の他はすべて植林され た人工林である。その樹林面積が $961 \mathrm{Km}^{2}$ で， 県下の総樹林面積の約 $26.5 \%$ ，県土の $20.4 \%$ と， 全国平均を上回っている。これらのスギの木は

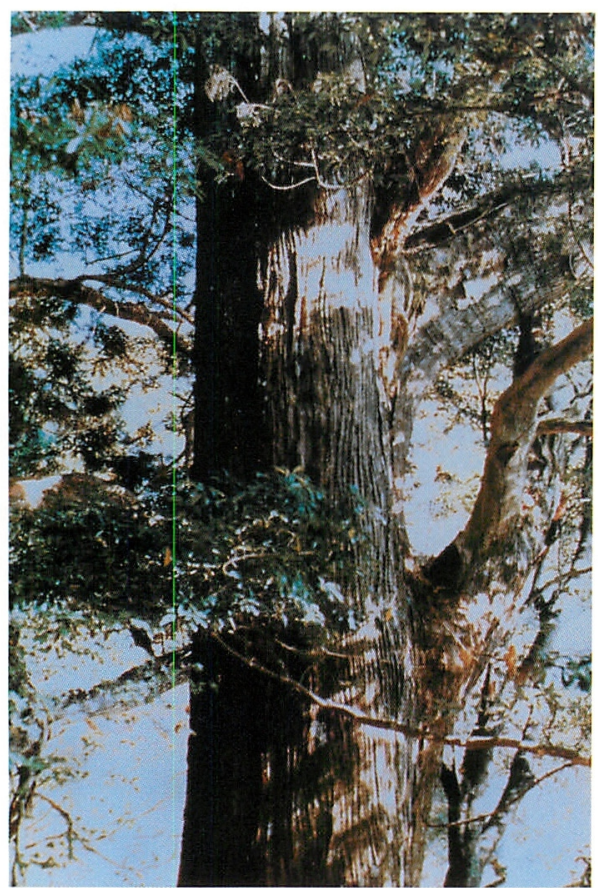

図 4 和歌山県天然記念物の「野中の一方杉」, 熊野 古道中程にあり，枝の全てが南を向いている.
毎年 $2 \sim 4$ 月になると多くの雄花芽からスギ花 粉を空中に飛散さす光景が和歌山県の各地でみ られる（図 5 )。以上の理由から，スギ花粉症 は多いと推定される。

スギ特異 $\operatorname{IgE}$ 抗体を持つ者すべてがスギ花 粉症とはいえないが，スギ RAST 陽性者に一 定の割合でスギ花粉症が発生するはずである. 著者ら 2223)（1986）は, 16歳以上の自然集団1491例 を対象として検討してみた。 その結果は表 2 に 示す通りである. RAST スコア 2 以上の者は 248 人で約 $13.9 \%$ の 人がスギ花粉症になる可能 性があることを示していた。ちなみに，この頻 度は東京都花粉症対策委員会 ${ }^{24)}$ が行った疫学 調查による秋川市 $6.5 \%$ (RAST スュア 2 以上, 1984年）や大田区蒲田西地区の7.3\%（1986年） よりも多い数字であり和歌山県の方がスギ花粉 症有病率が多いと推定する根拠になる。年齢別

表 2 年齢とスギ RAST 陽性者頻度の関係 $(\mathrm{n}=1491)$

\begin{tabular}{|c|c|c|c|c|c|c|}
\hline \multirow{2}{*}{ 年路 } & \multicolumn{5}{|c|}{ RAST スコア } & \multirow{2}{*}{$\begin{array}{l}\text { RAST } \\
\text { 陽性者 } \\
\text { 頻度 }(\%)\end{array}$} \\
\hline & 0 & 1 & 2 & 3 & 4 & \\
\hline $16-19$ & 140 & 4 & 12 & 14 & 5 & 17.7 \\
\hline $20-29$ & 288 & 9 & 48 & 33 & 1 & 21.6 \\
\hline $30-39$ & 260 & 15 & 21 & 23 & 3 & 14.6 \\
\hline $40-49$ & 240 & 8 & 22 & 9 & 1 & 11.4 \\
\hline $50-59$ & 223 & 5 & 9 & 4 & 0 & 5.4 \\
\hline $60-$ & 92 & 0 & 2 & 0 & 0 & 2.1 \\
\hline 計 & 1243 & 41 & 114 & 83 & 10 & 13.9 \\
\hline
\end{tabular}

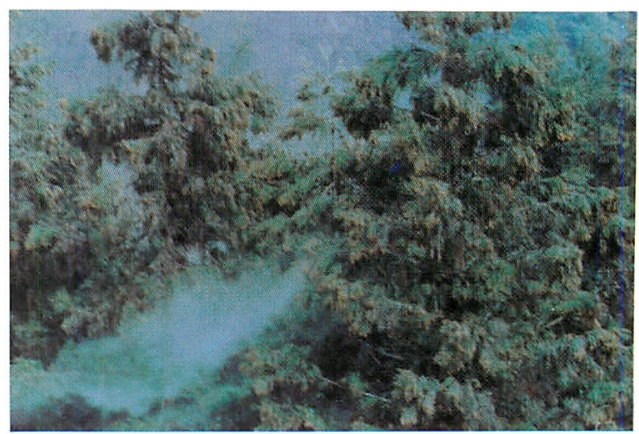

図 5 和歌山県下花園村でのスギ花粉飛散風景. 
では20歳代に多く $21.6 \%$, 次いで10歳代 $17.7 \%$, 以下 30 歳代 $14.6 \% ， 40$ 歳代 $11.4 \% ， 50$ 歳代 5.1 $\% ， 60$ 歳代 $2.1 \%$ の陽性率であり，20歳代が最 も多かった。諸家らの受診患者からみた成績と 一致した成績であった。

性別では男性 813 人中 156 人（15.9\%)，女性 678 人中 92 人（11.5\%）と男性に多いものの有 意差はなかった。

また，同調査 ${ }^{22)}$ で和歌山県のどの地域に多 いかについて, 各地町村の RAST 陽性頻度と の関係について検討したが，その結果，和歌山

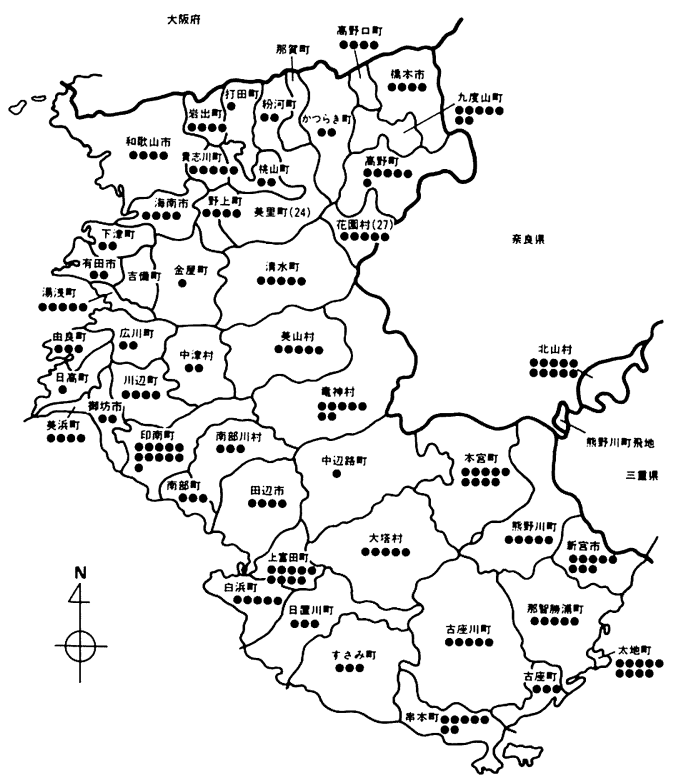

図 6 和歌山県下50市町村におけるスギ RAST 陽性 者頻度 (30例/市町村).
県では海岸部より山間部に多く，海岸部で多い ところはスギ花粉シーズンの $2 \sim 4$ 月に山側か らの風が吹いている, 紀南地方（和歌山県の南 部)，スギやスギと一部スギと共通抗原25）を持 つヒノキの樹林面積の多いところに·多かった (図 6 ).

\section{スギ花粉症は増加しつつあるか}

1. 本邦において

アレルギー疾患は増加しつつある26)。 スギ花 粉症も増加しつつある27) といらのが定説にな っている. 戦前にはスギ花粉症の医学知識がな かったことを割り引いても，戦前にスギ花粉症 は問題になっていなかったのであるから，戦後 増加したと考光るのが妥当であろう．小泉 ら 28 30)（1986，1987，1988）は日光地区の住 民を対象に，1974年から約 3 年毎スギ花粉症り 患率の疫学調査について検討している.1974年 には4\%であったのが10\%（1986年），20３0\% （1987年）と増加していると報告している。 の増加様式として, 斉藤らは, スギ花粉症患者 の既往歴の病悩歴から，スギ花粉症は徐々に増 加するものではなくスギ花粉の大量飛散の年に 感作されて増加するといら。しかし, 信太 ら ${ }^{3132)}$ （1986，1988）は相模原市で観測した年 次的花粉数の变動と斉藤らの受診スギ患者数の 変動との関係を見たもので, 花粉症に占めるス ギ花粉症の頻度は増加しているものの，スギ花 粉症のピークは過ぎたとする考兄られる報告を 行っている.

表 3 和歌山赤十字病院におけるスギ花粉症患者の年次的動向

\begin{tabular}{c|c|c|c|c|c}
\hline \hline & $\begin{array}{c}\text { 2月-5月の } \\
\text { 新患総数 }\end{array}$ & $\begin{array}{c}\text { 鼻アレルギー } \\
\text { 患者数 }\end{array}$ & $\begin{array}{c}\text { スギ花粉症 } \\
\text { 患者数 }\end{array}$ & $\begin{array}{c}\text { スギ花粉症の } \\
\text { 新患数に対する\% }\end{array}$ & $\begin{array}{c}\text { 鼻アレルギーに } \\
\text { 対する\% }\end{array}$ \\
\hline 昭和56年 & 2199 & 166 & 43 & 2.0 & 26.5 \\
57 年 & 2400 & 375 & 125 & 5.2 & 33.3 \\
58 年 & 2331 & 265 & 39 & 1.7 & 14.7 \\
59 年 & 2513 & 342 & 160 & 6.4 & 46.8 \\
60年 & 2441 & 308 & 154 & 6.4 & 50.0 \\
61年 & 2350 & 483 & 296 & 12.6 & 61.3 \\
62年 & 2042 & 309 & 193 & 9.5 & 54.5 \\
63年 & 2654 & 715 & 389 & 14.7 &
\end{tabular}


その増加の要因としては様々な説があり, 多 くの報告がある.すなわち, 戦後の植林政策の 不備や宅地等の土地の乱造成によるスギを取り 巻く環境が悪化による花粉数の増加, 食生活の 変化 (人工栄養児の増加, 人工添加剤, 人工着 色量等々の摂取）も含めた生活様式の变化，社 会的ストレス，大気污染等が考兄られている. このうち，大気污染に関しては新しい知見が報 告されている。亦なわち, 花粉症を含めた鼻了 レルギーの増加が都市部で著明なことから ${ }^{33)}$ 大気污染が増加の要因として取り上げられてい る。また，大気污染の大きな原因として自動車 排気ガスが問題にされ，大気污染物質の中のデ ィーゼル排出微粒子 (diesel exhaust particulate) に IgE 産生のアジュバント作用のある ことが報告されている34 36).

しかし, 単一の要因では解釈出来ない部分も あり，解明されなければならない種々の要因が 残されている.

2. 和歌山県に扮いて

和歌山県に括いて過去本症の推移を示す成績 はない，著者らは過去 8 年間のスギ花粉症患者 の動向をスギ花粉シーズンである $2 \sim 5$ 月に和 歌山赤十字病院を受診した新患総数で検討して みた．表 3 に示すよらに，スギ花粉の飛散が全 国的にあった1982年の翌年である1983年は患者 数が少ないものの， スギ花粉症が新患数に占め る割合でも鼻アレルギー患者に占める割合でも 年々増加しつつある。この成績は当科を受診す る患者の母集団も考慮にいれなければならない が，和歌山では増加しつつあることを示してい る.

\section{スギ花粉飛散数について}

図 7 は和歌山赤十字病院屋上で観測した各年 のスギ花粉飛散総数とその年に受診したスギ花 粉症患者の総数の関係を示したものである. 先 述したように，スギ花粉症の増加の要因の説は 様々であれ，スギ花粉飛散の多い年にはスギ花 粉症も多いことを如実に物語っている。したが って，日々の空中飛散スギ花粉数を測定するこ
とは重要なことであり，長期の観測を続けるこ とで，スギ花粉飛散数の予測を行学る可能性も あり，予防医学に役立てらると考えている。

1. 測定方法

種々な方法があるが37), durham 型花粉採取 器 (図 8 ) 38) が最もポピュラーで, 直系 $23 \mathrm{~cm}$ のステンレスの円盤に囲まれた中央に, 白色ワ セリンを塗布したスライドグラスを設置し，24 時間放置し，回収後染色し，カバーグラスに相 当するスライドグラス上の全花粉数をカウント し，その後 $1 \mathrm{~cm}^{2}$ 当りの花粉数に換算し成績と するのが一般的である。染色液としては $0.5 \%$ ゲンチアナバイオレットなどが用いられる。ま

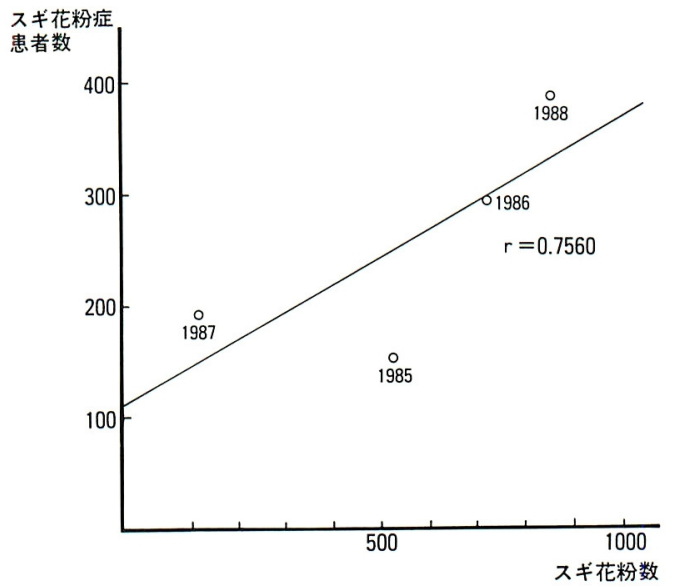

図 7 和歌山赤十字病院に和けるスギ花粉飛散数 （年）とスギ花粉患者数の関係.

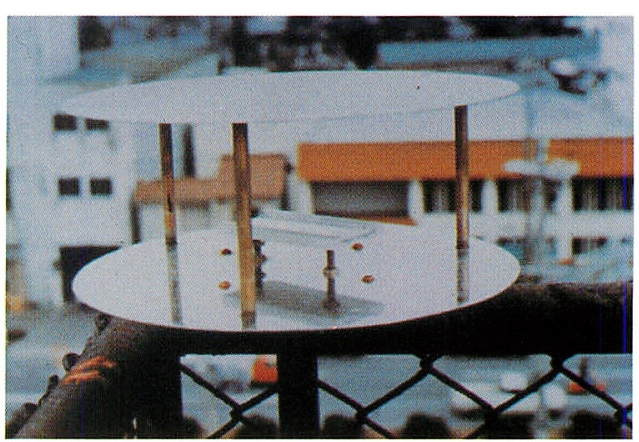

図 8 durham 米国標準型花粉補集器（和歌山赤十 字病院屋上). 
た，重力法では幾瀬，佐橋39）（1985）の考案に よるISロータリーといって, スライドホルダー を45度傾斜させさらに 2 枚の尾翼で常に風向き に向からようにして花粉補集効率を高めるよう にしたものがある。また，毎分 8.31 を吸引し， 体積法で検討するバーカード型花粉採取器 (英 国の Burkard 社の seven-day recording volumetric spore trap) も日本では十数カ所に 設置されている．著者らの病院の屋上にも置い ている(図 9 ).

2. 日本に叔计るスギ花粉の飛散の状況 スギ花粉飛散数を長期に観測した成績に，国 立相模原病院アレルギー研究部311) や国立療荃 所南福岡病院のものがある。また，東邦大学薬 学部生薬学教室 ${ }^{39)}$ や新潟市の藤崎医院 ${ }^{40)}$ (1988) でも続けられている。各地の飛散状態は各地で 異なるものの, 関東地方では昭和 51 年, 54 年, 57 年, 60 年, 63 年の 3 年周期で大量飛散があった と報告されている.

全国的な規模では1975年に編成された厚生省 花粉研究班（班長：長野準，国立南福岡病院院

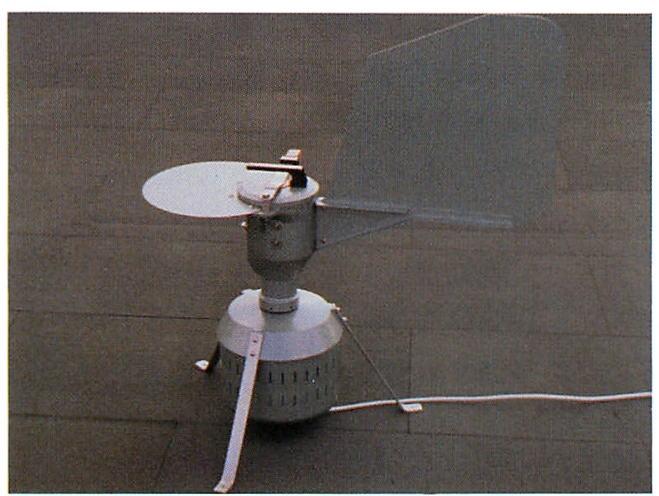

図 9 burkard 型花粉補集器（和歌山赤十字病院 屋上).
長）が全国で合計45施設で行った調査が有名で 1977年までの調査が41) ある。また，1986年か らは同班長のもとで「植物に起因寸るアレル ギ一疾患の基礎的・臨床的研究」, 1989年から は「花粉症に扮ける予防，治療関寸る研究」 (班長 : 西間三馨, 国立療養所南福岡病院院長) が 3 年間の予定で研究が続けられることになっ ている。

また，佐橋らは42) 44) $(1986,1987,1988)$ は全国数十力所ので測定されているスギ花粉飛 散開始日を等高線で結び，花粉前線と称し毎年 報告している.

3. 和歌山県におけるスギ花粉飛散について 和歌山県下では先述の班研究で調査された

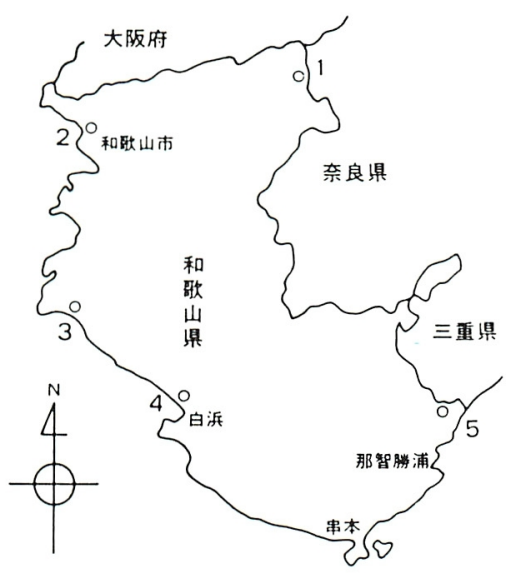

\begin{tabular}{l|ll}
\hline & \multicolumn{1}{|c}{ 測定場 所 } & \\
\hline 1 & 撟本市東家1-3-8 & 橋本市民病院屋上 \\
\hline 2 & 和歌山市小松原通4-1 & 和歌山赤十字病院屋上 \\
\hline 3 & 御坊市菌116-2 & 国保日高総合病院屋上 \\
\hline 4 & 田辺市港510 & 粑南総合病院屋上 \\
\hline 5 & 新宫市新宫451 & 新宮市民病院屋上 \\
\hline
\end{tabular}

図10 和歌山県拉よび大阪府南部における空中飛散 スギ花粉数測定地点.

表 4 近畿花粉症研究会の申し合わせに上る飛散開始日，飛散終了日

飛散開始日：飛散花粉数が $1 \mathrm{~cm}^{2}$ 当り 2 個以上の日, 西るいは $1 \mathrm{~cm}^{2}$ 当り 1 個以上の 日が 1 週間に 2 回以上あったとさはその最初の日とする.

飛散終了日：飛散花粉数が $1 \mathrm{~cm}^{2}$ 当り 2 個以上の日, あるいは $1 \mathrm{~cm}^{2}$ 当り 1 個以上の 日が 1 週間に 2 回以上あったときはその最後の日とする. 
1976，1977年の成績41）があるが，それ以前や 以降の測定の報告はない。そこで, 著者 ら 45) 49)（1986，1987，1989）は1985年より， 和歌山県下と大阪府の南部の 6 力所 (図10) に durham 型採取器を設置し, 空中花粉飛散数を 測定し，その結果について報告してきた。なお， 飛散開始日, 飛散終了日は著者の 1 人である榎 本が世話人をする近畿花粉研究会の申し合わせ に従っている（表 4 ）。過去 4 年間の飛散状況 は表 5 の通りで, 和歌山県では飛散開始日は早 く, 南に位置する新宮市から北に向かってほぼ 順に飛散が開始し，飛散終了も比較的遅い傾向 にある．年度別の飛散総数は新宮市のように背 後にスギの森林を控えるところや，橋本市のよ らに四方が山で囲まれているところでは多く飛 散していたが，その他の地域では余り多くない. また，関東の 3 年周期に比べ 2 年周期で飛散数 が多かった.

\section{飛散花粉数の予測}

1. 飛散花粉数予測の諸説

スギ花粉の飛散数について予測することは， 本症の予防医学の見地からも重要なことである. スギ花粉飛散予測に関寸るものには，表 6 に示 すような種々な方法50) 56) が報告されている. 大別して, 翌年の飛散総数の予測, 飛散開始日 の予測, シーズン中の日々の予測がある.

1）翌年の飛散総数の予測

スギ花粉の飛散数は前年 $7 \sim 8$ 月の気象状況 に大きく左右されることが報告されている，そ れは， スギ花粉の雄花芽の分化がその時期にお
こるためである57)58). 山崎ら ${ }^{50) 51 ）}(1979,1984 ）$ は飛散数の予測は前年度の 7 月の平均気温が平 年值より $1^{\circ} \mathrm{C}$ あるいはそれ以上に高いとさに スギ花粉飛散数は著しく増加するとしている。

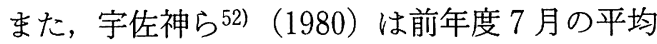
湿度と関係があり，花粉飛散総数は，表 6 亿示 す式で予測できるとしている。また，王ら53) （1988）は前年度 7 月11日から 8 月10日の最高 気温の平均と高い相関を示すとしている.

2）飛散開始日にの予測

飛散開始日に関して, 柴原ら ${ }^{54)}$ （1988）は飛 散開始の時期は 1 月 1 日からの最高気温の累積 が $300^{\circ} \mathrm{C}$ に達したとさに飛散が始まるとして いる。また，宗ら55)（1988）は 1 月の平均気温 と 1 月上旬の降水量より, 表 6 に示す予測式を 立て飛散開始日の予測を行っている. 山崎56) （1983）も飛散開始日の予測は可能であるとし ている.

\section{3）日々の予測}

日々の花粉数は, 柴原ら ${ }^{54 ） （ 1988 ） に よ る と, ~}$ 翌日の予想最高気温から予測できる（表 6 ）.

2. 和歌山地方に捺ける予測

1）過去に打ける飛散の予測

1988年の飛散花粉予測に関して, 著者ら59 （1988）は, 前年度の気象や着花の状態からや や増加するが，余り多くないとした（表 7 ）が, しかし非常に多い年であった。また，1989年の 予測では，晚期飛散，飛散数少量と予測した60). 確かに, 1989年は飛散が少なかったものの, 暖 冬のため早期飛散型であった。これらの事実は,

表 5 和歌山県および大阪府南部における過去 4 年間のスギ花粉飛散状況

\begin{tabular}{|c|c|c|c|c|c|c|c|c|c|c|c|c|}
\hline & \multicolumn{3}{|c|}{ 1985年 } & \multicolumn{3}{|c|}{ 1986年 } & \multicolumn{3}{|c|}{ 1987年 } & \multicolumn{3}{|c|}{ 1988年 } \\
\hline & $\begin{array}{l}\text { 飛散 } \\
\text { 開始 }\end{array}$ & $\begin{array}{l}\text { 飛散 } \\
\text { 終了 }\end{array}$ & $\begin{array}{l}\text { 飛散 } \\
\text { 総数 }\end{array}$ & $\begin{array}{l}\text { 飛散 } \\
\text { 開始 }\end{array}$ & $\begin{array}{l}\text { 飛散 } \\
\text { 終了 }\end{array}$ & $\begin{array}{l}\text { 飛散 } \\
\text { 総数 }\end{array}$ & $\begin{array}{l}\text { 飛散 } \\
\text { 開始 }\end{array}$ & $\begin{array}{l}\text { 飛散 } \\
\text { 終了 }\end{array}$ & $\begin{array}{l}\text { 飛散 } \\
\text { 総数 }\end{array}$ & $\begin{array}{l}\text { 飛散 } \\
\text { 開始 }\end{array}$ & $\begin{array}{l}\text { 飛散 } \\
\text { 終了 }\end{array}$ & $\begin{array}{l}\text { 飛散 } \\
\text { 総数 }\end{array}$ \\
\hline 和歌山市 & $2 / 5$ & $5 / 22$ & 521 & $2 / 22$ & $5 / 7$ & 717 & $2 / 7$ & $4 / 9$ & 114 & $1 / 23$ & $4 / 20$ & 851 \\
\hline 橋本市 & $\ldots$ & $\ldots$ & $\cdots$ & $2 / 22$ & $4 / 21$ & 3243 & $2 / 4$ & $4 / 8$ & 666 & $1 / 22$ & $4 / 20$ & 2388 \\
\hline 御坊市 & $\cdots$ & $\cdots$ & $\ldots$ & $2 / 15$ & $5 / 8$ & 1907 & $2 / 4$ & $4 / 7$ & 479 & $1 / 30$ & $4 / 18$ & 1396 \\
\hline 田辺市 & $\cdots$ & $\cdots$ & $\cdots$ & $2 / 21$ & $5 / 22$ & 611 & $2 / 12$ & $4 / 4$ & 467 & $2 / 10$ & $4 / 23$ & 786 \\
\hline 新宮市 & $\cdots$ & $\cdots$ & $\cdots$ & $1 / 4$ & $4 / 30$ & 2952 & $2 / 6$ & $4 / 3$ & 437 & $1 / 6$ & $4 / 23$ & 2410 \\
\hline 泉佐野市 & $\cdots$ & $\cdots$ & $\cdots$ & $\cdots$ & $\ldots$ & $\cdots$ & $2 / 13$ & $3 / 28$ & 102 & $2 / 2$ & $4 / 26$ & 1450 \\
\hline
\end{tabular}


各地の予測は各地のスギの着花の状態61）から 推測すべきであり，各地方で独自の予測方法の 確立する必要があることを示唆している。

表 7 和歌山市における1988年のスギ花粉飛散量の 予測

\begin{tabular}{|c|c|}
\hline 検 討 項 目 & 予想 \\
\hline 平均気温（前年度 7 月） & O \\
\hline 平均湿度（前年度 7 月） & $x$ \\
\hline 日最高気温（前年度 7 月 11 日～ 8 月 10 日） & $\bigcirc$ \\
\hline 日照時間（前年度 7 月 11 日〜 8 月 10 日） & $x$ \\
\hline 着花の状態 & 0 \\
\hline
\end{tabular}

2）和歌山市の独自の予測方法

（1） スギ花粉飛散総数の予測

過去の飛散スギ花粉数と前年の日最高気温の 関係を見た. 日最高気温の積算に際し, 積算日 を 6 月 1 日より 8 月 31 日までとし積算日数を 5 日間から60日間とすると，21通りで，日最高気 温とスギ花粉飛散数の間には相関があることが 有意にいえた $(\mathrm{P}<0.05)$. 5 日間や6 日間とい ら短期の積算では信頼性が低いと考えられるの で，積算日数を 20 日間以上にとるのが良いと考 えられる. しかし，この方法で1989年の飛散花 粉数を予測すると，今までの観測期間が 4 年と 短いせいか，予測值は負の值が出てしまうので, 必ずしもよい予測方法ではない。

表 6 スギ花粉予測に関する報告

1. 山崎ら (1979)

前年度 7 月の気温 $>$ 平年値 $\left(1^{\circ} \mathrm{C} \leqq\right)$ 飛散数の著明増加

前年度 7 月の気温 $>$ 平年值 $\left(0 \sim 1^{\circ} \mathrm{C} \leqq\right)$ 飛散数の增加

前年度 7 月の気温 $<$ 平年值 飛散数の増加

2. 宇佐部 (1980)

前年度 7 月の平均湿度が関係

平均気温が $23.9^{\circ} \mathrm{C}$ 以上の時

飛散花粉数 $=-330 \times($ 前年度 7 月の平均湿度 $)+28336$

3. 王ら (1988)

前年度 7 月 11 日から 8 月 4 日までの 25 日間の日最高気温の平均と高い相関

4. 山崎ら (1983)

1 月 29 日から 2 月 4 日にかけての 7 日間の平均気温が飛散開始日を決定する

平均気温 $(1 / 29 \sim 2 / 4)<0.6^{\circ} \mathrm{C} \quad 2$ 月 21 日 +8 日

$0.6^{\circ} \mathrm{C}<$ 平均気温 $(1 / 29 \sim 2 / 4) \leqq 5.4^{\circ} \mathrm{C} \quad 2$ 月 21 日 \pm 3 日

$5.4^{\circ} \mathrm{C}<$ 平均気温 $(1 / 29 \sim 2 / 4) \quad 2$ 月 21 日 -8 日

5. 柴原ら (1988)

飛散開始の時期は 1 月 1 日からの最高気温の累積が $300^{\circ} \mathrm{C}$ に達したときに飛散が始まる.

6. 宗ら (1988)

飛散開始日は, 1 月の平均気温及び 1 月上旬の降水量と高い相関がある.

(飛散開始日を 2 月の日付と仮定すると)

飛散開始日 $=38.207-3.754 \times(1$ 月の平均気温 $)-0.179 \times(1$ 月上旬の降水量 $)$

7. 柴原ら (1988)

日々の花粉数は以下の式で予測される.

$\mathrm{Y}=\mathrm{aX}+\mathrm{b}$

$\mathrm{Y}$ : スギ花粉予測量 $\mathrm{a}$ : 定数項 $\mathrm{X}$ : 翌日の予想最高気温 $\mathrm{b}$ : 定数項 
（2）飛散開始日の予測

飛散開始日に関してであるが，過去の方 法54) 56) では和歌山市のように 1 月に飛散が 開始（1988年）する地域で使用できない。また，

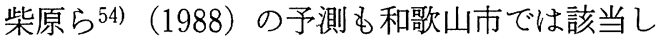
なかった。そそこで，日最高気温の起算日を 1 月 1 日以前にし検討寸ると，前年 9 月29日よりの 積算が最も関係していた。しかし，1989年は暖 冬であり，飛散開始が遅れるとの予測とは逆に， 比較的早期から飛散が開始していた。

以上のことは，飛散に関する予測が如何に困 難であるかを示唆するもので, 各地域での長期 の花粉数の長期にわたる測定とその詳細な解析 が必要であることを物語っている.

\section{スギ花粉飛散の予報に関して}

最近，飛散予報がトピックスとなっている． 飛散予報の現状と将来について考えてみたい。

1. 日本に抽ける花粉予報の現状

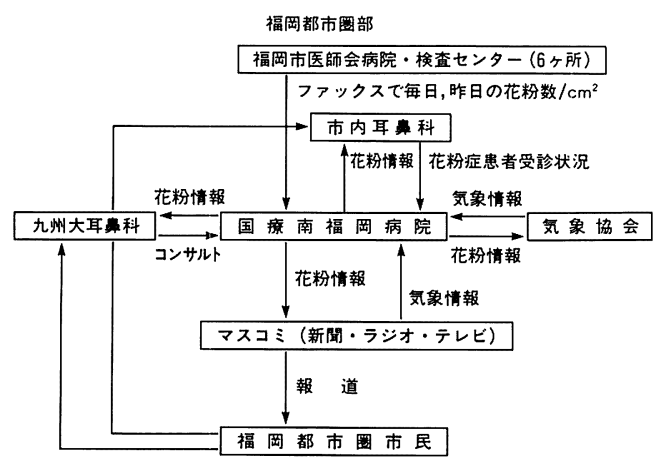

図11福岡都市圏部花粉情報システム（長野 準, 他 : 198862) $)$.

表 8 重回帰分析による日々のスギ花粉数と気象の 関係

\begin{tabular}{l|r|r|c}
\hline \hline 説明変数 & 回㷌計数 & \multicolumn{1}{c|}{$\mathrm{t}$ 值 } & 信頼水準 \\
\hline 最高気温 & 0.054903 & 0.727127 & 53.256811 \\
最低気温 & -0.228342 & -1.976897 & 95.148932 \\
雲量 & 0.115643 & 0.726219 & 53.201256 \\
最大風速 & 0.560238 & 2.281766 & 97.714773
\end{tabular}

$\mathrm{Y}$ 切 片: 0.255140

重相関計数 : 0.119444

信 頼 水準 : $92.677 \%$
スギ花粉の飛散を予測し，実際に公表してい る地方としては, 東京地方, 京都地方, 福岡地 方62)，その他多くの地区がある.

東京地方では，東京医科歯科大学耳鼻咽喉科 を中心にして花粉情報を出している．京都地方 では，京都府立医科大学耳鼻咽喉科が中心にな って予測をたて ${ }^{63)}$ ，京都新聞に飛散の程度（飛 散低調・中等度・活発の 3 段階）の予測と医学 的アドバイスを含んだ情報を提供している。福 岡地方では国立療養所南福岡病院を中心として， 福岡市内 13 力所のスギ花粉飛散数の測定結果と 同病院の過去16年間のデータをもとに予測式を 立て，その結果を毎日，気象，飛散状況，花粉 症状況, 医学的アドバイスを含んだ情報をつ、 ックスにて各報道機関へ送り，新聞や文字放送 を利用して報道している（図11）。小笠原ら ${ }^{64}$ （1988）も兵庫県で花粉予報を実際に新聞で予 報しその結果を報告しているが，まだその的中 率は $57.5 \%$ である.

2. 和歌山に括けるスギ花粉予報の可能性に つ小

著者らは, 気象台から得られた気象学的デー タをもとに，重回帰分析を行った。その結果， スギ花粉飛散数は当日の日最低気温, 平均気温, 雲量, 最大風速, 一日降水量と高い相関を示し た、しかし，気象台が行ら翌日の予報は，日最 高気温, 日最低気温, 最大風速, 雲量等である ので，これをもとに分析を行らと表 8 に示す通 りで，日最低気温と最大風速に高い相関を示し ていた。この結果を用いることで，花粉予報が 実施できそらであるが，通常日最高気温が上昇 した時に飛散数が増加するが，全項目を用いた 解析では負の回帰計数になってしまっている. つまり日最高気温が上昇すればスギ花粉飛散数 は減少するといら矛盾した結果が出ている。し かし，説明変数を 4 つに絞ると，逆に日最高気 温は正の回帰計数となるなど, 説明変数のとり かたで矛盾した成績が出てくる。したがって， 正確な予測方法には長期の花粉観測の成績が必 要になってくる．長期の観測，他の地域の密な 
連絡による情報の交換，マス・メディアの選択 等も解決しなければならない重要なポイントで, これらを解決しつつ和歌山市に执ける早期の花 粉予報の実現を考えている。

\section{治療について}

I 型アレルギー疾患の予防や治療の原則は原 因抗原から回避することにあることはいらまで もない，そのために，転地療法も考学られるが， 様々な制約により非現実的である. メガネやつ ばの広い帽子の装用，帰宅時上着の塵埃を払う などの事柄が一般的で推奨されている.しかし， 現実問題としては，薬物療法に頼らざるを得な い.すでに多くの報告があり，紙面の都合もあ るので, 詳細は譲りたい。抗ヒスタミン剂, ス テロイド剤，抗アレルギー剤（脱顆粒抑制剤） 等々の薬物があるが, 薬物治療の要点はこれら の薬剤をうまく組み合わせて使用することが肝 要である. 特に, 抗アレルギー剂は, 内服剂65) のみならず眼や鼻への局所使用剤(66)67) も開発さ れてきているので本症の治療にらまく取り入れ たい，さらに，スギ花粉シーズンの $2 \sim 4$ 週間 前から使用することで予防的効果 ${ }^{68 \sim 71)}$ も得る ことができる．また，予防投薬他の薬剤でもそ の効果が認められている72)73). しかし，この系 統の薬剤は薬剤間で多少作用機序が異なってい て，症例によりその効果も若干異なる。したが って，効果がなければいたずらに長期に使用せ

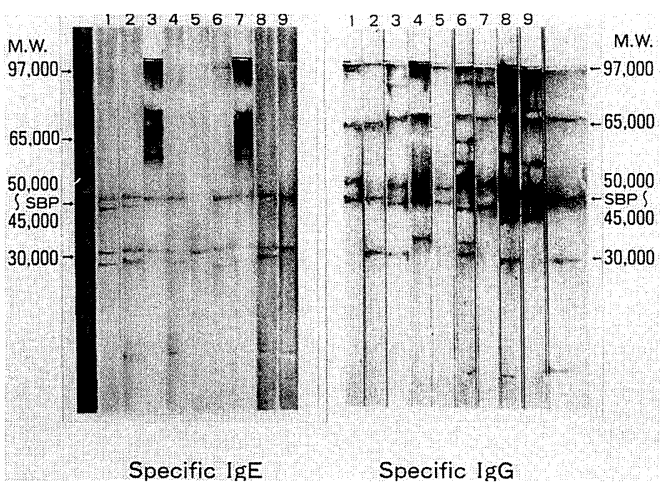

図12 スギ粗抗原抽出液とスギ花粉患者血清による ウエスタンブロッテングによるスギ特異 $\operatorname{IgE}$ と特異 IgG 抗体.
ず作用機序の違うものに切り替えることが必要 である。

ところで，特異的免疫療法 ${ }^{74)}$ は少なくとも， 免疫アレルギー学に多少手を染めたものにとっ ては最も興味のある治療方法である. Noon ら75)（1911）によってブタクサ花粉によって始 められた減感作療法はスギ花粉症でも行われて いる. 減感作療法の効果発現程度としては, blocking antibody の産生, 特異的 IgE 産生の 減少，標的細胞である好塩基球や肥満細胞から の化学伝達物質の遊離抑制などが考兄られてい る. スギの減感作療法で興味ある減感作の方法 としては, 経口減感作療法76) がある。西端・

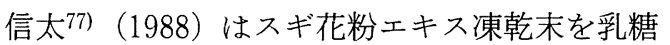
を容れた経口用のカプセルにいれ，毎日服用さ せている, その結果, 脱落例 $44.4 \%$ の残りの全 ての症例に効果があり，有効例約 $50 \%$ であった と報告している. 経口減感作は方法論として脱 落例も比較的少なくかなりの効果が得られてい るが，一般にスギの減感作療法はその効果発現 までの期間が長く, 脱落例が多く, 有効率も一 般に低い。著者らは，HD 等の重複感作例にの みスギと HD の減感作療法を施行している. また, 国立相模原病院では安枝ら 78799 (1980， 1983）の抽出したスギ主要抗原 sugi basic protein (SBP) による減感作療法を行って その有効率を高めようとしている. 最近, 井上 ら 80）（1988）は本療法の治療効果の向上を計る ため，前記の SBP に多糖体プルランを結合さ せ, アレルゴイドの形として特異 $\operatorname{IgE}$ の産生 は抑えられるが特異 $\operatorname{IgG}$ 抗体産生を増強させ る試みを動物実験系で試みている。また，その 臨床応用を試みている. 今後の研究に期待した

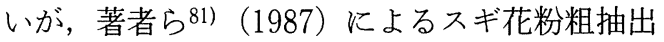
液と患者血清によるウェスタンブロッティング の成績では，スギ花粉は SBP 以外に多くのア レルゲンを持って括り，患者によっては SBP 以外のアレルゲンを認識し, その特異 $\operatorname{IgE}$ 抗 体を持つ患者もいるし，産生されている特異 IgG 抗体も様々である（図12）。したがって, 


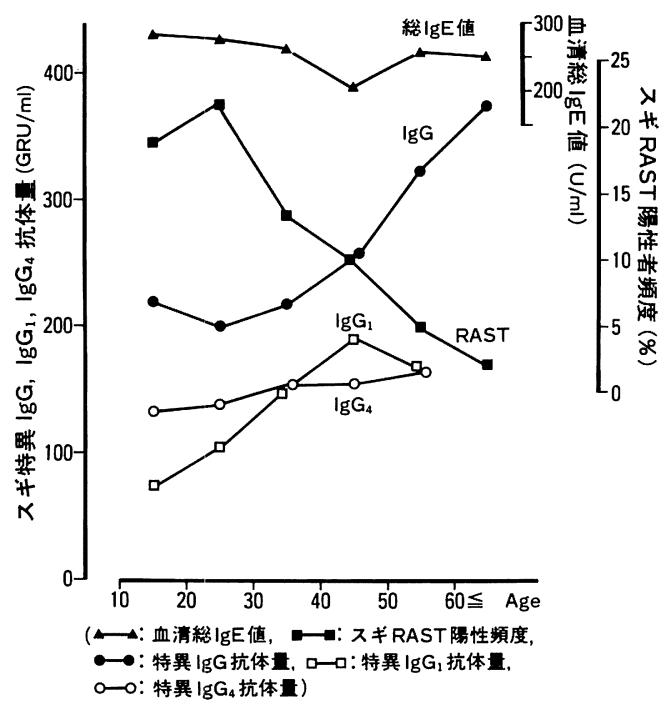

図13 自然集団における加㱓と血清総 $\operatorname{IgE}$ 值, スギ RAST 陽性者頻度, スギ特異 IgG 抗体量, 特 異 IgG1, 特異 IgG4 抗体量の関係.

特異 IgG 抗体の意味するところをより詳細に

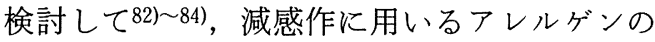
精製程度を慎重に選択しなければならないと考 えている。 また，同方法で多種の特異 IgG 抗 体も検出されるのでどの特異 $\mathrm{IgG}$ 抗体やサブ クラスの産生の増強を狙らのかを明確にして拉 く必要もあろう. 著者ら ${ }^{83)}$ (1989）のなぜスギ 花粉症が20３0歳代に多いのかについて自然集 団を対象に検討した結果の，加齢によるスギ RAST 陽性者頻度の減少, 特異 IgG の増加, 特異 IgG1 抗体の増加といった現象の詳細な解 析が役に立つかも知れない（図13）.

免疫学的療法としては，I 型アレルギー85)86) の最近の進歩を背景とするスギ特異 $\operatorname{IgE}$ 抗体 産生系の制御87) が最終の目的であろら。その ためには, 特異 $\mathrm{IgG}$ 抗体の投与, $\mathrm{B} \varepsilon$ 細胞のト レランス誘導, スギ花粉特異的サプレッサーT 細胞76) の誘導, $\operatorname{IgE}$ 特異的サプレッサーT細 胞88) の誘導が考兄られるが，現在研究が進め られているものの実用段階にない。

おわりに

最近増加しつつあるスギ花粉症について著者
らの和歌山県に拈ける研究を中心に最近の知見 も交兄ながら述べてきたが，本症の発症メカニ ズムの主役はあくまでもI 型アレルギーである． スギ花粉症が将来まだ増加し続けるのかを考光 ることは興味ある。アレルゲン側から考光ると， 戦後植林したスギの木が現在沢山に花粉を飛散 させているので，新たに植林しなければ飛散数 が減少し，その発症が少なくなる可能性がある. さらに，将来風向などの気象条件を考虑して， 居住地に出来るだけ遠い地域に植林したり, 植 林した樹木の管理をより義務づけることで，患 者の数が減少するであろう。これには, 山林経 営者の自覚や行政面からの強い指導が必要にな る. 同時に, 上り詳細な疫学調査や基礎的研究 を必要とするが, 特異 $\operatorname{IgE}$ の抗体産生にアジ ュバント作用を持つとされるディーセル排気ガ スや大気污染物質のより強力な規制を行うこと で発症率の低下を計ることも大切であろう。こ れにも, 産業界の自覚と強力な行政指導が必要 となる。

抗体側から考光れば，リンパ球のサブクラス をも含めた特異 $\operatorname{IgE}$ 産生系, 特異 $\operatorname{IgG}$ 産生系 のより詳細な検討, 同時に $\operatorname{IgE}$ 産生系の制御 を追求していくことで，究極の目的であるスギ 花粉症を根本的に治療できる日がくることと固 く信じている．この両者の側からの, 組織だっ たより強力なアプローチが本邦の国民病ともい えるスギ花粉症を根治する唯一の道であると考 えている.

本研究の花粉数の測定は, 上記の著者以外に和歌 山県花粉研究会のメンバー, 芦辺好, 吉内光夫 (和 歌山赤十字病院), 加藤宽 (和歌山県立医科大学), 上田和義（橋本市民病院）, 白井楥, 鈴木政伸, 林泰 弘, 田端弘幸, 植本英宣, 寒川真仁, 畑忠良, 山内 啓子, 岩崎有紀子, 堀田美奈子, 西田美智子, 田, 岡治美 (国保日高総合病院), 田中孝, 玉置達紀, 坂 口幸作, 大久保雅吏, 竹中正人, 滝浪やよひ, 山本 博子, 東山将治, 竹部侑二 (紀南総合病院), 橋立俊 司（新宮市民病院）, 奥野吉昭（拈くの耳鼻咽喉科） らによったことを付記する。 


\section{文献}

1）水谷民子, 藤崎洋子, 馬場 実, 他: ハンノキ 花粉喘息. アレルギー $20: 700 〜 705,1971$.

2）藤崎洋子：花粉症の研究II 新潟地方に打ける八 ンノキ花粉症. 日児誌 $78: 403 \sim 412,1974$.

3）堀口申作, 斉藤洋三: 栃木県日光地方に批ける スギ花粉症 Japanese Cedar Pollinosis の発見. アレルギー 13:16〜18, 1964.

4）古内一郎: 花粉症, 特にスギ花粉症について. 日医大誌 $48: 461 \sim 467,1981$.

5）降矢和夫：花粉症に関する研究（II）花粉症に おケるコナラ属植物の意義. アレルギー 19 ： 918 930, 1970.

6）我妻義則, 松山隆治, 能戸 浩, 他: 花粉症の 研究 (V) 札幌地方のシラカンバ花粉症. アレ ルギー $21: 710 〜 717,1972$.

7）芦田恒雄, 松永 喬, 井手 武, 他: スギ花粉 症とヒノキ花粉症. 花粉誌 $31: 7 \sim 14,1985$.

8）清水章治, 信太隆夫 : ケヤキ花粉症の 1 例. ア レルギー $25: 291,1976$. (抄録)

9）藤崎洋子: 花粉症の研究 $N$ マッ花粉症. アレル ギー 9:668〜677, 1976.

10）榎本雅夫：木の花粉によるアレルギー，スギを 中心として.Pharma Medica 4: 127〜131, 1986.

11）貝塚 侊: 花粉症の歴史. JOHNS $4: 135 \sim 139$, 1988.

12）小曾戸丈夫, 浜田善利 : 意釈黄帝内經素問. 6 頁, 築地書館, 東京, 1971.

13）荒木英斉: 花粉症の研究. アレルギー 9:648 $\sim 655,1960$.

14）斎藤洋三編著 : スギ花粉症. すずさわ書店, 東 京, 1980.

15）古内一郎：スギ花粉症一予防と最新治療法. 婦 人生活社, 東京, 1980 .

16）信太隆夫監修：図説スギ花粉症. 金原出版, 東 京, 1983.

17）中村 晋：気管支喘息における杉花粉への感作. アレルギニ゙ $8: 589,1987$.

18）榎本雅夫, 中西 弘, 吉内光夫, 他 : 問診用紙 による鼻アレルギーの疫学調査. 和赤医誌 4 : 108〜114, 1986.

19）奥田 稔: 発症機序. 図説スギ花粉症（信太隆 夫監修). 51 69頁, 金原出版, 東京, 1983.

20）榎本雅夫, 吉内光夫, 榎本多津子 : 樹木花粉と
鼻アレルギー（第 3 報）17，8歳女子に护ける 樹木花粉特異的 IgE 抗体について. 基礎と臨 床 $19: 2325 \sim 2328,1985$.

21）榎本雅夫, 横山道明, 中西 弘, 他: 樹木花粉 と鼻アレルギー（第14報）スギ RAST 陽性者 にみられる他のアレルゲンの重複感作. 基礎と 臨床 $23: 665 \sim 669,1989$.

22）榎本雅夫, 吉内光夫, 岩橋大介, 他 : 樹木花粉 と鼻アレルギー（第 5 報）和歌山県下 50 市町村 におけるスギ IgE RAST による疫学的調査.

日耳鼻 $89: 595 \sim 604,1986$.

23）榎本雅夫, 吉内光夫, 岩橋大介, 他 : 樹木花粉 と鼻アレルギー（第 6 報）加令とスギ $\operatorname{IgE}$ RAST 陽性者の関係. 耳鼻臨床 $79: 1333 \sim 1337$, 1986.

24）斉藤洋三 : 花粉症診療の最近の話題一特集アレ ルギーの臨床一. 内科 $59: 677 \sim 681,1987$.

25）宮本昭正, 降矢和男, 水野勝之: 花粉間の共通 抗原性に関する研究. アレルギー $20: 39 \sim 40$, 1971.

26）宮本昭正：アレルギーの過去・現在・未来. ア レルギア $17: 1 \sim 6,1988$.

27）岸川禮子, 西間三馨 : スギ花粉症増加の要因. MEDICO 20:17 26: 1989 .

28）小泉一弘, 石崎 達, 池森享介: スギ花粉症患 者に扣ける飛散花粉量と感作との関係. アレル ギー $35: 891,1986$.

29）九嶋 敦, 大橋祐二, 小泉一弘, 他: 栃木県日 光地区におけるスギ花粉症の出現頻度. アレル ギー $36: 588,1987$.

30）小泉一弘, 鈴木修二: スギ花粉症の疫学. アレ ルギー, 今日の考え方 $4: 17 \sim 19,1988$.

31）信太隆夫, 西端慎一, 相馬幸子: 相模原市にお ける過去 20 年間の空中花粉検索と花粉患者の推 移. 植物に起因するアレルギー症の基礎的臨床 的研究報告書. 63 65頁, 1988.

32）信太隆夫：相模原市に打ける過去20年間の空中 飛散花粉検索之花粉症患者の推移. 花粉誌 32 : 41 49, 1986.

33）遠藤朝彦：集団検診における鼻副鼻腔炎の診断 をめぐる諸問題一都市と農村における鼻副鼻空 疾患に関する疫学とその問題点一. 日本鼻科学 会誌 $21: 267 \sim 274,1983$.

34) Muranaka M, Suzuki S. Koizumi K, et al : Ad- 
juvant activity of diesel-exhaust particulates for the production of IgE antibody in mice. $J$ Allergy Clin Immunol 77 : 616 623, 1986.

35) Takafuji S, Suzuki S, Koizumi K, et al : Dieselexhaust particulate inoculated by the intranasal route have an adjuvant activity for $\operatorname{IgE}$ production in mice. J Allergy Clin Immunol $79: 639 \sim$ $645,1987$.

36）小泉一弘：スギ花粉症と大気污染. JOHNS 4 : 219〜227, 1988.

37）竹田栄子：空中花粉調查とその現状. JOHNS 4 : 159 163, 1988.

38) Durham OC: The volumetric incidence of atomsheric allergens. J Allergy $17: 79 \sim 86$, 1946.

39）佐橋紀夫：アレルギー性疾患検查法, 飛散アレ ルゲンIII.アレルギーの臨床 $5: 1141 \sim 1146$, 1985.

40）藤崎洋子：新潟市にお将る過去15年間の空中花 粉調查結果と花粉症患者の奉態. 花粉誌 34 : $19 \sim 30,1988$.

41）長野 準, 勝田満江，信太隆夫：日本列島の空 中花粉. 北隆館, 東京, 1978 .

42）佐橋紀夫：1986年のスギ花粉前線. 花粉誌 32 : 29 34, 1986.

43）佐橋紀夫：1987年のスギ花粉前線. 花粉誌 33 : $59 \sim 64,1987$.

44）佐橋紀夫：1988年のスギ花粉前線. 花粉誌 34 : $79 \sim 86,1988$.

45）榎本雅夫, 生駒貴子, 古川恵子, 他 : 樹木花粉 と鼻アレルギー（第 4 報）和歌山赤十字病院屋 上における飛散樹木花粉. 耳鼻臨床 $79: 135$ ～ 142, 1986.

46）榎本雅夫, 生駒貴子, 古川惠子, 他 : 和歌山赤 十字病院屋上に拈ける昭和 60 年度の飛散花粉に ついて. 和赤医誌 $4: 105 \sim 107,1986$.

47）榎本雅夫, 生駒貴子, 中西 弘, 他 : 樹木花粉 と鼻アレルギー（第 7 報）和歌山県下における 昭和 61 年度のスギ花粉飛散状況について. 耳展 $30: 211 \sim 216,1987$.

48）榎本雅夫, 生駒貴子, 中西 弘, 他：樹木花粉 と鼻アレルギー（第 8 報）和歌山県下に拈ける 昭和62年のスギ花粉飛散状況について一. 花粉 誌 $33: 103 \sim 110,1987$.
49）中西 弘, 榎本雅夫, 横山道明, 他 : 樹木花粉 と鼻アレルギー（第13報）一和歌山県, 大阪府 南部における昭和63年のスギ花粉飛散数一.耳 鼻臨床 82 : 391 398, 1989.

50）山崎 太, 水野瑞夫, 信太隆夫, 他 : 花粉症起 因花粉の研究（第一報） スギ花粉飛散数の早期 予測について.アレルギー $28: 732 \sim 737,1979$.

51）山崎 太 : 花粉症起因花粉の研究（第 8 報）昭和59年春のスギ花粉飛散量と前年 7 月の平均 気温との相関について一. 医学と薬学 $12: 344$ $\sim 346,1984$.

52）宇佐神篤，降矢和夫，遠藤久子，他：スギ花粉 空中花粉数の予測. アレルギー $29: 780 \sim 785$, 1980.

53）王 主栄：スギ花粉産性量および飛散開始日と 気象の関係. JOHNS 2 : 185〜195, 1988.

54）柴原義博, 高坂知節：スギ花粉予報の方法と検 討. JOHNS $2: 191 \sim 195,1988$.

55）宗 信夫，岸川禮子：スギ花粉飛散予測と予測 式について. JOHNS 2 : 197〜200, 1988.

56）山崎 太 : 花粉症起因花粉の研究（第 7 報）岐阜におけるスギ花粉飛散開始日の予測—. 医 薬の門 $23: 26 \sim 29,1983$.

57）橋詰準人：スギの花芽分化期および花芽の生育 経過について. 日林誌 $44: 312 \sim 319,1962$.

58）橋詰準人：針葉樹の花芽分化，花性分化とその 調節. 林木の育種 $44: 312 \sim 319,1962$.

59）榎本雅夫, 中西 弘, 寒川高男, 他 : 樹木花粉 と鼻アレルギー（第12報）一和歌山市における 昭和63年度のスギ花粉飛散の予測一，基礎と臨 床 $22: 857 \sim 861,1988$.

60）中西 弘, 榎本雅夫, 横山道明, 他 : 和歌山市 における平成元年のスギ花粉飛散の予測. アレ ルギーの臨床 $9: 217 〜 221,1989$.

61）高橋祐一, 山口勝一, 阿部悦子, 他：雄花芽形 成量を用いた来シーズンのスギ花粉飛散総数予 測の試み. 第 7 回耳鼻咽喉科免疫アレルギー研 究会抄録 25 頁, 1989.

62）長野 準，井上 栄，信太隆夫，他：植物に起 因するアレルギー症の基礎的臨床的研究報告書 （昭和62年度厚生省研究費による）77～85頁， 1988.

63）竹中 洋, 水越 治: 花粉情報システムの試み. JOHNS 2 : 201 206, 1988. 
64）小笠原寛：兵庫県のスギ花粉飛散状況々予報. 日本鼻科学会誌 $27: 255,1988$.

65）榎本雅夫, 中西 弘, 寒川高男, 他 : アレルギー 性鼻炎に対する AA673 錠の臨床的検討. 耳鼻 臨床 81 : 1223 1234, 1988.

66）榎本雅夫, 中西 弘, 岩橋大介：アレルギー性 鼻炎に対するAA673 点鼻液の臨床的検討. 耳 鼻臨床 $80: 1151 \sim 1162,1987$.

67）榎本雅夫, 横山道明, 中西 弘, 他 : 通年性了 レルギー性鼻炎に対する Ketotifen 点鼻液の臨 床的検討. 耳展 1989 (印刷中)

68）木村廣行, 矢島 洋, 羽田達正 : スギ花粉症に おける予防的投薬の検討一（I）DSCG， Tranilast の予防効果一. 耳鼻 $32: 416 \sim 424$, 1986.

69）吉見龍一郎，今里 滋，中田孝重：スギ花粉症 の治療，アゼラスチンの季節前投与. 耳展 31 補 $1: 1 \sim 6,1988$.

70）奥田 稔, 矢島 洋, 古内一郎, 他 : スギ花粉 症におけるトラニラストの季節前投与による予 防効果. 耳展 $30: 219 \sim 243,1987$.

71）滝口清徳, 兼子順男, 遠藤朝彦, 他 : スギ花粉 症に対する Ketotifen の花粉飛散前予防的投薬 の効果. 耳展 $30: 71 \sim 81,1987$.

72）小島未知郎, 占部成二, 宮崎 充: スギ花粉症 の予防投薬一ヒスタグロビン注射による一.耳 鼻 $33: 969 \sim 972,1987$.

73）荻野 敏, 入船盛弘, 原田 保, 他：スギ花粉 症に対するヒスタミン加ヒト免疫グロブリンの 花粉飛散前投与の効果について.耳鼻臨床 81 : $759 \sim 767,1988$.

74）藤田洋祐：スギ花粉症に対する減感作療法. ア レルギーの臨床 1：20～25, 1982.

75) Noon L : Prophylactic inoculation against hay fever. Lancet I : 1672, 1911.

76）清水章治，安枝 浩：スギ花粉症患者への経口 減感作療法の試み.アレルギー $32: 594,1983$.

77）西端慎一，信太隆夫：経口減感作療法，植物に 起因するアレルギー症の基礎的臨床的研究報告 書(昭和62年度厚生省研究費による) 57 ～60頁， 1988.

78）安枝 浩, 由井泰雄, 清水章治, 他：スギ花粉 アレルゲンの分析. アレルギー $29: 763 \sim 772$,
1980.

79) Yasueda $H$, Yui $Y$, shimizu $T$, et al : Isolation and partial characterization of the major allergen from Japanese cedar (cryptomeria japonica) pollen. J Allergy Clin Immunol 71 : $77 \sim 86,1983$

80）井上栄, 臼井美津子, 松橋 直: スギ花粉了 レルゴイドによる減感作の試み. 植物に起因す るアレルギー症の基礎的臨床的研究報告書（昭 和62年度厚生科学研究費による） $75 ＼mathrm{~ 76 頁, ~}$ 1988.

81) Enomoto T, Nakanishi H, Samukawa T, et al : Tree pollens and nasal allergy (IX) Specific IgE and IgG antibodies to Japanese cedar pollen as determined by electroblotting. Med JWRCH $5: 140 \sim 144,1987$.

82）榎本雅夫, 吉内光夫, 中西 弘: 樹木花粉と鼻 アレルギー（第10報）ELISA を用いたスギ特 異的 IgG および IgG4 抗体測定の基礎的検討. 基礎と臨床 $21 ： 461 \sim 466,1987$.

83）榎本雅夫, 横山道明, 中西 弘, 他 : 樹木花粉 と鼻アレルギー（第11報）加歯と血清総 $\operatorname{IgE}$ 值,スギ RAST スコア, スギ特異 IgG 抗体, IgG subclass 抗体量の関係について. 日耳鼻 $92: 597 \sim 601,1989$.

84）榎本雅夫, 中西 弘, 岩橋大介, 他 : HD 减感 作療法による臨床症状と DP 特異的 IgG 抗体 の変動について．耳鼻臨床 $79: 1803 \sim 1809$, 1986.

85) Ishizaka $\mathrm{K}$ : Cellular events in the IgE antibody response. Adv Immunol $23: 1 \sim 75,1976$.

86) Kishimoto $T:$ IgE class-specific supressor $T$ cells and regulation of the IgE response. Prog Allergy $19: 265 \sim 317,1982$.

87）末村正樹：アレルギーの免疫療法一 $\operatorname{IgE}$ 抗体の 制禦.アレルギーの臨床 $5: 808 〜 812,1985$.

88）本多一至, 笹月健彦: 花粉症の遺伝. JOHNS 4 : 213 218, 1988.

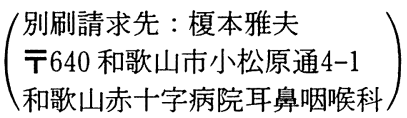

